JURNAL GEOGRAFI

Geografi dan Pengajarannya

ISSN 1412 - 6982

e-ISSN : 2443-3977

Volume XVIII Nomor 1 Juni 2020

\title{
STRATEGI ADAPTASI SISWA DALAM MENGHADAPI BENCANA BANJIR SEBAGAI UPAYA MITIGASI BENCANA DI SD DAN MI MUHAMMADIYAH KECAMATAN BAYAT
}

\author{
Asna Nur Rachma \\ Universitas Muhammadiyah Surakarta \\ Surakarta - Indonesia
}

\begin{abstract}
Abstrak : Penelitian ini bertujuan untuk mengetahui kerawanan bencana banjir berdasarkan data historis banjir dan mengetahui strategi adaptasi siswa di SD Muhammadiyah Bayat dan MI Muhammadiyah Talang Kecamatan Bayat dalam menghadapi bencana banjir. Penelitian ini menggunakan pendekatan kuantitatif. Pendekatan ini lebih menekankan pada analisis dari penelitian yang akan dilakukan dan menggunakan hasil dari analisis untuk membandingkan antara satu dengan yang lain. Penelitian ini ditujukan kepada siswa kelas 5 dan siswa kelas 6 SD Muhammadiyah Bayat dan MI Muhammadiyah Talang Kecamatan Bayat yang tergolong dalam sekolah dasar rawan akan bencana banjir. Menurut data historis yang didapat dari kuesioner yang disebar ke responden, kerawanan banjir di SDM PK dan MIM Talang Bayat bisa dikatakan cukup tinggi karena lokasi sekolah yang berdekatan dengan Sungai Dengkeng dan untuk siswa kelas 5 dan kelas 6 SDM PK Bayat sudah sedikit mengetahui strategi adaptasi apa yang harus dilakukan sebelum dan saat terjadi banjr, karena siswa mempunyai pengalaman ketika banjir melanda rumah mereka. Strategi adaptasi siswa dalam menghadapi bencana banjir di MIM Talang Bayat termasuk dalam tingkat sedang karena rata-rata siswa telah mengerti hal apa saja yang harus dilakukan sebelum dan saat banjir.
\end{abstract}

Kata kunci : kerawanan banjir, lokasi, strategi adaptasi

\section{A. PENDAhUluan}

Banjir merupakan suatu masalah yang sampai saat ini masih perlu adanya penanganan khusus dari berbagai pihak, baik dari pemerintah maupun masyarakat. Bencana banjir tidak dapat tidak dapat dihindari, tetapi dapat diminimalisir dampaknya dengan cara penanggulangan terhadap banjir.

Menurut Robert J. Kodatie dan Roestam Sjarief (2006), ada 5 macam strategi untuk mengurangi dampak banjir pada individu dan masyarakat, yaitu informasi dan pendidikan, asuransi banjir, penyesuaian-penyesuaian pajak, tindakan-tindakan darurat untuk banjir dan pemulihan pasca banjir. Banjir sering kali menjadi masalah bagi sebagian masyarakat, khususnya masyarakat yang tinggal di daerah dataran rendah maupun di bantaran sungai.

Kecamatan Bayat yang berada di Kabupaten Klaten, Provinsi Jawa Tengah merupakan salah satu wilayah yang berada di selatan dan memiliki karakter wilayah yang rentan terhadap beberapa bencana alam, salah satunya yaitu banjir. Kecamatan Bayat merupakan wilayah yang berada di bantaran sungai. Sungai Dengkeng merupakan salah satu sumber 
adanya bahaya banjir di Kecamatan Bayat. Terdapat beberapa sekolah dasar di Kecamatan Bayat yang juga terancam terkena dampak resiko dari adanya bencana banjir, yaitu SD Muhammadiyah Bayat, MI Muhammadiyah Talang dan masih ada beberapa sekolah lainnya. Menurut data BPS Kabupaten Klaten Kecamatan Bayat dalam angka 2018 luas wilayah Desa Talang sebesar $1,89 \mathrm{Km}^{2}$ dengan tinggi daerah sebesar 141 mdpl.Kecamatan Bayat memiliki jumlah penduduk lakilaki sebesar 32.497 jiwa dan perempuan sebesar 32.183 jiwa.

Tindakan adaptasi terhadap bencana banjir dapat berupa tindakan yang dilakukan untuk mengurangi dampak bencana baik dampak secara langsung maupun tidak langsung (Gissing et al., 2004). Upaya adaptasi juga bertujuan untuk memastikan bahwa sumber daya yang diperlukan untuk tanggap dalam peristiwa bencana dapat digunakan secara efektif pada saat bencana dan tahu bagaimana menggunakannya (Sutton and Tierney, 2006). Berdasarkan masalah diatas, maka peneliti tertarik untuk mengkaji lebih dalam mengenai bagaimana strategi adaptasi siswa SD Muhammadiyah Bayat dan MI Muhammadiyah Talang Kecamatan Bayat Kabupaten Klaten dalam menghadapi bencana banjir yang dijadikan sebagai upaya mitigasi bencana sejak dini.

\section{B. METODE PENELITIAN}

Penelitian ini menggunakan pendekatan kuantitatif. Pendekatan ini lebih menekankan pada analisis dari penelitian yang akan dilakukan dan menggunakan hasil dari analisis untuk membandingkan antara satu dengan yang lain. Penelitian ini ditujukan kepada siswa kelas 5 dan siswa kelas $6 \mathrm{SD}$ Muhammadiyah Bayat dan MI Muhammadiyah Talang Kecamatan Bayat yang tergolong dalam sekolah dasar rawan akan bencana banjir dan digunakan untuk analisis strategi adaptasi siswa dalam menghadapi bencana banjir.

Teknik Sampling yang digunakan dalam penelitian ini yaitu nonprobability sampling dengan teknik purposive sampling. Alasan menggunakan teknik purposive sampling karena tidak semua sampel memiliki kriteria yang sesuai dengan fenomena yang diteliti.

Adapun sekolah dasar dan siswa yang dijadikan sampel dalam penelitian ini adalah SD Muhammadiyah PK Bayat dengan sampel 83 siswa yang terdiri dari 48 siswa kelas 5 dan 35 siswa kelas 6 dan juga MIM Talang Bayat dengan sampel 28 siswa yang terdiri dari 13 siswa kelas 5 dan 15 siswa kelas 6. 


\section{HASIL DAN PEMBAHASAN}

\section{Kerawanan Banjir di Sekolah Berdasarkan Data Historis}

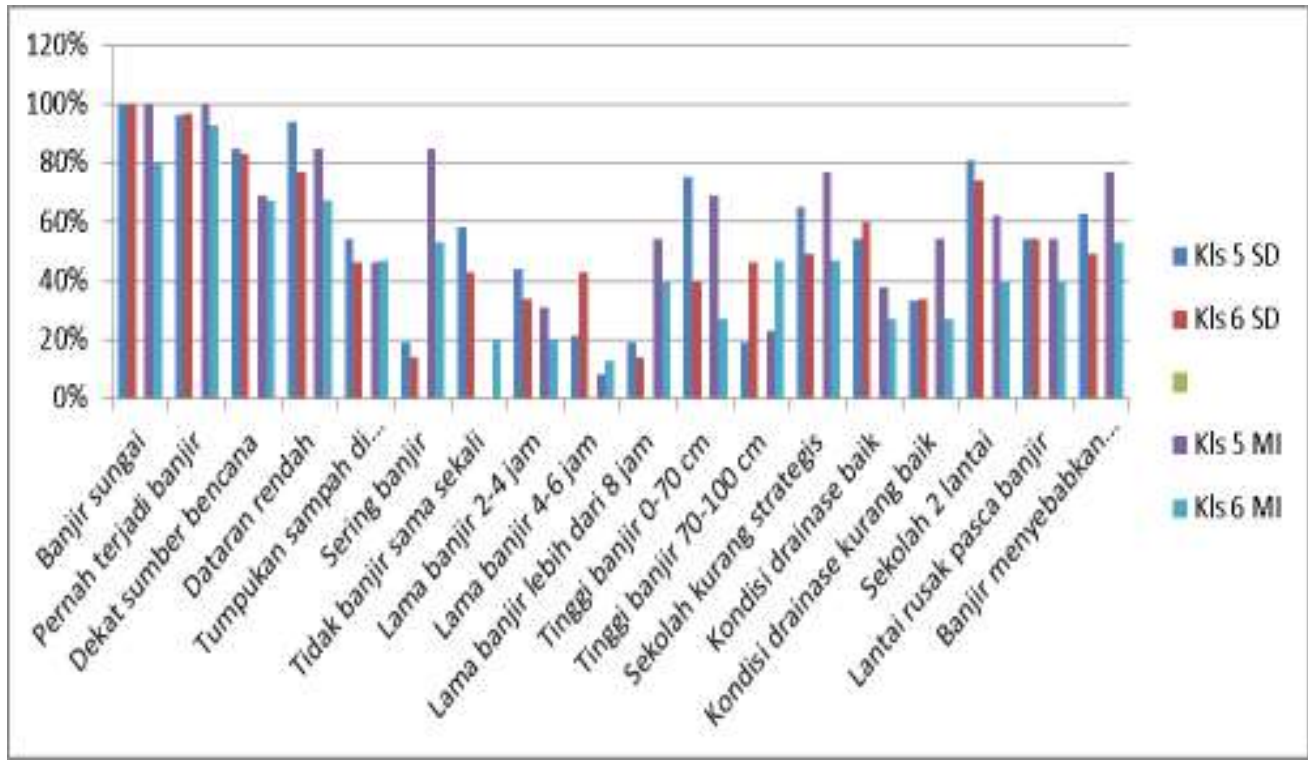

Seluruh siswa kelas 5 dan kelas 6 SDM PK Bayat berpendapat bahwa jenis banjir yang sering terjadi di daerah sekolahnya saat musim penghujan adalah banjir sungai karena letak sekolah yang berdekatan dengan sumber bencana banjir yaitu Sungai Dengkeng. Menurut pendapat kepala sekolah SDM PK Bayat, jarak antara lokasi sekolah dengan Sungai Dengkeng kurang lebih sekitar 100 meter.

Beberapa siswa kelas 5 dan kelas 6 SDM PK Bayat berpendapat bahwa banjir yang sering terjadi di daerah sekolahnya disebabkan karena tumpukan sampah di saluran air yang menyebabkan tersumbatnya air dan terjadi banjir. Tentang hal tersebut pada kelas 5 lebih tinggi dibanding dengan kelas 6, dibuktikan dengan persentase yang lebih tinggi pada kelas 5. Dilihat dari persentase tentang indikator ini, maka sangat dibutuhkan pemahaman yang baik dan benar pada siswa tentang penyebab banjir, agar di aplikasikan oleh siswa sehingga dapat mengurangi risiko bencana.

Sebagian besar siswa kelas 5 dan kelas 6 SDM PK Bayat berpendapat bahwa ketinggian tempat atau topografi di kawasan sekolahnya berada pada dataran rendah. Pengetahuan tentang ketinggian tempat atau topografi pada kelas 5 lebih tinggi dibanding dengan kelas 6, dibuktikan dengan tingginya persentase pada kelas 5 sebesar $94 \%$ dan kelas 6 sebesar 77\%. Dilihat dari persentase kelas 6 sebesar $77 \%$ maka masih diperlukan pemahaman tentang ketinggian tempat atau topografi pada 
siswa di SDM PK Bayat khususnya kelas 6.

Persentase untuk indikator sering banjir pada kelas 5 sebesar $19 \%$ dan kelas 6 sebesar 14\%. Sedangkan persentase untuk indikator tidak banjir sama sekali pada kelas 5 sebesar 58\% dan kelas 6 sebesar $43 \%$. Persentase antara kelas 5 dan kelas 6 lebih tinggi pada indikator tidak banjir sama sekali, artinya sebagian besar siswa kelas 5 dan kelas 6 SDM PK Bayat berpendapat bahwa tidak terjadi banjir sama sekali di sekolahnya, hal ini adalah pendapat siswa setelah sekolah dalam keadaan sudah di renovasi menjadi lebih tinggi dari akses jalan ke sekolah. Kepala sekolah SDM PK Bayat mengatakan bahwa sebelum sekolah di renovasi, banjir sering masuk kedalam sekolah dan proses belajar mengajar sempat harus di hentikan untuk sementara waktu. Setelah adanya renovasi di sekolah, banjir yang parah sebagian besar hanya terjadi di akses jalan ke sekolah. Akses jalan sekolah yang tidak lancar, seperti jalan yang tergenang banjir dapat menyebabkan proses belajar mengajar jadi terhambat.

Persentase untuk indikator lama banjir 2-4 jam pada kelas 5 sebesar 44\% dan kelas 6 sebesar 34\%. Persentase untuk indikator lama banjir 4-6 jam pada kelas 5 sebesar 21\% dan kelas 6 sebesar $43 \%$. Persentase untuk indikator lama banjir lebih dari 8 jam pada kelas 5 sebesar $19 \%$ dan kelas 6 sebesar $14 \%$. Indikator lama banjir menunjukan bahwa persentase tertinggi kelas 5 berada pada indikator lama banjir 2-4 jam sebesar $44 \%$ dan persentase tertinggi kelas 6 berada pada indikator lama banjir 4-6 jam sebesar 43\%. Sedangkan untuk persentase terendah dari masing-masing kelas berada pada indikator lama banjir lebih dari 8 jam, persentase kelas 5 sebesar $19 \%$ dan kelas 6 sebesar $14 \%$. Hal ini menunjukan sebagian besar siswa kelas 5 berpendapat bahwa lama banjir di wilayah sekolahnya selama kurang lebih 2-4 jam, sedangkan sebagian besar siswa kelas 6 berpendapat bahwa lama banjir di wilayah sekolahnya selama kurang lebih 4-6 jam.

Persentase untuk indikator tinggi banjir $0-70 \mathrm{~cm}$ pada kelas 5 sebesar $75 \%$ dan kelas 6 sebesar 40\%. Persentase untuk indikator tinggi banjir 70-100 cm pada kelas 5 sebesar $19 \%$ dan kelas 6 sebesar $46 \%$. Indikator tinggi banjir menunjukan bahwa persentase tertinggi kelas 5 berada pada indikator tinggi banjir $\quad 0-70 \mathrm{~cm}$ sebesar $75 \%$ dan persentase tertinggi kelas 6 berada pada indikator tinggi banjir 70-100 cm sebesar 46\%. Hal ini menunjukan bahwa sebagian besar siswa kelas 5 berpendapat bahwa tinggi banjir di wilayah sekolahnya sekitar 0-70 cm, sedangkan sebagian besar siswa kelas 6 berpendapat bahwa tinggi banjir di wilayah sekolahnya sekitar 70-100 cm. 
Persentase untuk indikator kondisi drainase baik pada kelas 5 sebesar 54\% dan kelas 6 sebesar 60\%. Persentase untuk indikator kondisi drainase kurang baik pada kelas 5 sebesar 33\% dan kelas 6 sebesar 34\%. Persentase tertinggi setiap kelas terdapat pada indikator kondisi drainase baik. Hal tersebut menunjukan bahwa sebagian besar siswa kelas 5 dan kelas 6 SDM PK Bayat berpendapat bahwa kondisi drainase atau got yang ada di wilayah sekolah mereka termasuk dalam kategori baik. Akan tetapi masih ada sebagian kecil siswa yang berpendapat bahwa kondisi drainase atau got yang ada di wilayah sekolah mereka termasuk dalam kategori kurang baik. Artinya masih diperlukan pemahaman tentang kondisi drainase yang baik pada siswa SDM PK Bayat, khususnya pada kelas 5 dan kelas 6, dengan pemahaman tersebut kepada siswa dapat membantu dalam menjaga kondisi drainase agar terjaga dengan baik.

Sebagian besar siswa kelas 5 dan kelas 6 SDM PK Bayat berpendapat bahwa lantai sekolah mereka terdiri dari 2 lantai. Artinya untuk pengetahuan tentang hal ini, siswa kelas 5 dan kelas 6 sudah cukup paham, karena memang SDM PK Bayat terdiri dari 2 lantai. Akan tetapi ada beberapa siswa kelas 5 dan kelas 6 SDM PK Bayat yang berpendapat bahwa sekolah tersebut kurang strategis, karena berdekatan dengan sungai dan untuk sampai di sekolah pada saat musim penghujan harus melewati jalan yang sulit dilalui karena adanya banjir yang cukup parah.

Pengetahuan dan pemahaman tentang akibat dari adanya banjir terhadap sekolah pada siswa kelas 5 dan kelas 6 SDM PK Bayat dikategorikan sama. Hal tersebut dibuktikan dari persentase untuk indikator lantai rusak pasca banjir pada kelas 5 sebesar 54\% dan kelas 6 sebesar 54\%. Sebagian besar siswa kelas 5 dan kelas 6 SDM PK Bayat berpendapat bahwa kemungkinan yang akan terjadi pada sekolah pasca terjadi banjir adalah lantai sekolah yang rusak. Pendapat siswa tersebut berdasarkan pengalaman siswa saat terjadi banjir di kawasan sekolahnnya.

Sebagian besar siswa kelas 5 dan kelas 6 SDM PK Bayat berpendapat bahwa banjir dapat menyebabkan kerugian sekolah. Siswa berpendapat demikian karena merasa proses belajarnya terganggu saat terjadi bencana banjir. Artinya siswa kelas 5 dan kelas 6 cukup menyadari bahwa banjir dapat menyebabkan kerugian sekolah maupun yang lain, akan tetapi pengetahuan dan pemahaman tentang bencana banjir maupun tentang mitigasi bencana banjir di SDM PK Bayat harus lebih di tingkatkan agar siswa dapat mengaplikasikannya ke kehidupan sehari-hari dan dapat dijadikan sebagai 
pembantu dalam pengurangan risiko bencana banjir.

Sebagian besar siswa kelas 5 dan kelas 6 MIM Talang Bayat berpendapat bahwa jenis banjir yang sering terjadi di daerah sekolahnya saat musim penghujan adalah banjir sungai karena letak sekolah yang berdekatan dengan sumber bencana banjir yaitu Sungai Dengkeng. Menurut pendapat kepala sekolah MIM Talang Bayat, jarak antara lokasi sekolah dengan Sungai Dengkeng kurang lebih sekitar 250 meter. Beberapa siswa atau setengah dari kelas 5 dan kelas 6 MIM Talang Bayat berpendapat bahwa banjir yang sering terjadi di daerah sekolahnya disebabkan karena tumpukan sampah di saluran air yang menyebabkan tersumbatnya air dan terjadi banjir. Pengetahuan tentang hal tersebut pada kelas 6 sedikit lebih tinggi dibanding dengan kelas 5, dibuktikan dengan persentase yang lebih tinggi pada kelas 6 . Dilihat dari persentase tentang indikator ini, maka sangat dibutuhkan pemahaman yang baik dan benar pada siswa tentang penyebab banjir, agar di aplikasikan oleh siswa sehingga dapat mengurangi risiko bencana.

Sebagian besar siswa kelas 5 dan kelas 6 MIM Talang Bayat berpendapat bahwa ketinggian tempat atau topografi di kawasan sekolahnya berada pada dataran rendah. Pengetahuan tentang ketinggian tempat atau topografi pada kelas 5 lebih tinggi dibanding dengan kelas 6, dibuktikan dengan tingginya persentase pada kelas 5 sebesar $85 \%$ dan kelas 6 sebesar 67\%. Dilihat dari persentase kelas 6 sebesar $67 \%$ maka masih diperlukan pemahaman tentang ketinggian tempat atau topografi pada siswa di MIM Talang Bayat khususnya kelas 6.

Persentase untuk indikator sering banjir pada kelas 5 sebesar $85 \%$ dan kelas 6 sebesar 53\%. Sedangkan persentase untuk indikator tidak banjir sama sekali pada kelas 5 sebesar $0 \%$ dan kelas 6 sebesar $20 \%$. Persentase antara kelas 5 dan kelas 6 lebih tinggi pada indikator sering banjir, artinya sebagian besar siswa kelas 5 dan kelas 6 MIM Talang Bayat berpendapat bahwa sering terjadi banjir di kawasan sekolahnya. Menurut hasil penelitian yang telah dilakukan, hal tersebut dikarenakan letak sekolah yang masih berada di bawah akses jalan atau dalam artian lebih tinggi akses jalan sehingga memudahkan air untuk masuk kedalam lingkungan sekolah yang dapat menyebabkan terjadinya banjir dan juga keadaan sekolah yang minimalis atau belum direnovasi. Kepala sekolah MIM Talang Bayat mengatakan bahwa pada saat musim hujan dan posisi air Sungai Dengkeng meluap yang dapat menyebabkan wilayah disekitarnya mengalami banjir, salah satunya yaitu MIM Talang Bayat yang sering terkena banjir dan menyebabkan proses belajar 
mengajar harus di hentikan untuk sementara waktu sampai banjir reda dan keadaan sekolah memungkinkan untuk melangsungkan proses belajar mengajar.

Persentase untuk indikator lama banjir 2-4 jam pada kelas 5 sebesar 31\% dan kelas 6 sebesar 20\%. Persentase untuk indikator lama banjir 4-6 jam pada kelas 5 sebesar $8 \%$ dan kelas 6 sebesar $13 \%$. Persentase untuk indikator lama banjir lebih dari 8 jam pada kelas 5 sebesar 54\% dan kelas 6 sebesar $40 \%$. Indikator lama banjir menunjukan bahwa persentase tertinggi pada kelas 5 dan kelas 6 berada pada indikator lama banjir lebih dari 8 jam. Sedangkan untuk persentase terendah dari masing-masing kelas berada pada indikator lama banjir 4-6 jam, persentase kelas 5 sebesar 8\% dan kelas 6 sebesar 13\%. Hal ini menunjukan sebagian besar siswa kelas 5 dan kelas 6 berpendapat bahwa lama banjir di wilayah sekolahnya selama lebih dari 8 jam, artinya untuk menunggu banjir di wilayah sekolah surut membutuhkan waktu yang cukup lama hingga lebih dari 8 jam, maka baru bisa dilaksanakan proses belajar mengajar di sekolah.

Persentase untuk indikator tinggi banjir 0-70 $\mathrm{cm}$ pada kelas 5 sebesar $69 \%$ dan kelas 6 sebesar 27\%. Persentase untuk indikator tinggi banjir 70-100 cm pada kelas 5 sebesar 23\% dan kelas 6 sebesar $47 \%$. Indikator tinggi banjir menunjukan bahwa persentase tertinggi kelas 5 berada pada indikator tinggi banjir $\quad 0-70 \mathrm{~cm}$ sebesar $69 \%$ dan persentase tertinggi kelas 6 berada pada indikator tinggi banjir 70-100 $\mathrm{cm}$ sebesar 47\%. Hal ini menunjukan bahwa sebagian besar siswa kelas 5 berpendapat bahwa tinggi banjir di wilayah sekolahnya sekitar 0-70 $\mathrm{cm}$, sedangkan sebagian besar siswa kelas 6 berpendapat bahwa tinggi banjir di wilayah sekolahnya sekitar 70-100 cm

Persentase untuk indikator kondisi drainase baik pada kelas 5 sebesar 38\% dan kelas 6 sebesar 27\%. Persentase untuk indikator kondisi drainase kurang baik pada kelas 5 sebesar $54 \%$ dan kelas 6 sebesar 27\%. Persentase tertinggi setiap kelas terdapat pada indikator kondisi drainase kurang baik. Hal tersebut menunjukan bahwa sebagian besar siswa kelas 5 dan kelas 6 MIM Talang Bayat berpendapat bahwa kondisi drainase atau got yang ada di wilayah sekolah mereka termasuk dalam kategori kurang baik. Akan tetapi masih ada sebagian kecil siswa yang berpendapat bahwa kondisi drainase atau got yang ada di wilayah sekolah mereka termasuk dalam kategori baik. Artinya masih diperlukan pemahaman tentang kondisi drainase yang baik pada siswa MIM Talang Bayat, khususnya pada kelas 5 dan kelas 6, dengan pemahaman tersebut kepada siswa dapat membantu dalam 
menjaga kondisi drainase agar terjaga dengan baik.

Sebagian besar siswa kelas 5 dan kelas 6 MIM Talang Bayat berpendapat bahwa lantai sekolah mereka terdiri dari 2 lantai. Artinya untuk pengetahuan tentang hal ini, siswa kelas 5 dan kelas 6 sudah cukup paham, karena memang MIM Talang Bayat terdiri dari 2 lantai akan tetapi hanya terdiri satu ruang untuk kelas 6 dengan kondisi yang tidak baik. Beberapa siswa kelas 5 dan kelas 6 MIM Talang Bayat berpendapat bahwa sekolah tersebut kurang strategis, karena berdekatan dengan sungai dan untuk sampai di sekolah pada saat musim penghujan harus melewati jalan yang sulit dilalui karena adanya banjir yang cukup parah.

Pengetahuan dan pemahaman tentang akibat dari adanya banjir terhadap sekolah pada siswa kelas 5 dan kelas 6 MIM Talang Bayat memiliki persentase yang cukup besar. Hal tersebut dibuktikan dari persentase untuk indikator lantai rusak pasca banjir pada kelas 5 sebesar 54\% dan kelas 6 sebesar 40\%. Sebagian besar siswa kelas 5 dan kelas 6 MIM Talang Bayat berpendapat bahwa kemungkinan yang akan terjadi pada sekolah pasca terjadi banjir adalah lantai sekolah yang rusak. Pendapat siswa tersebut berdasarkan pengalaman siswa saat terjadi banjir di kawasan sekolahnnya, dan pendapat tersebut diperkuat karena adanya kegiatan bersihbersih sekolah khususnya lantai sekolah saat pasca bencana banjir.

Sebagian besar siswa kelas 5 dan kelas 6 MIM Talang Bayat berpendapat bahwa banjir dapat menyebabkan kerugian sekolah. Siswa berpendapat demikian karena merasa proses belajarnya terganggu saat terjadi bencana banjir. Artinya siswa kelas 5 dan kelas 6 cukup menyadari bahwa banjir dapat menyebabkan kerugian sekolah maupun yang lain, akan tetapi pengetahuan dan pemahaman tentang bencana banjir maupun mitigasi bencana banjir di MIM Talang Bayat harus lebih di tingkatkan agar siswa dapat mengaplikasikannya ke kehidupan sehari-hari dan dapat dijadikan sebagai pembantu dalam pengurangan risiko bencana banjir. 


\section{Strategi Adaptasi Siswa dalam Menghadapi Bencana Banjir}

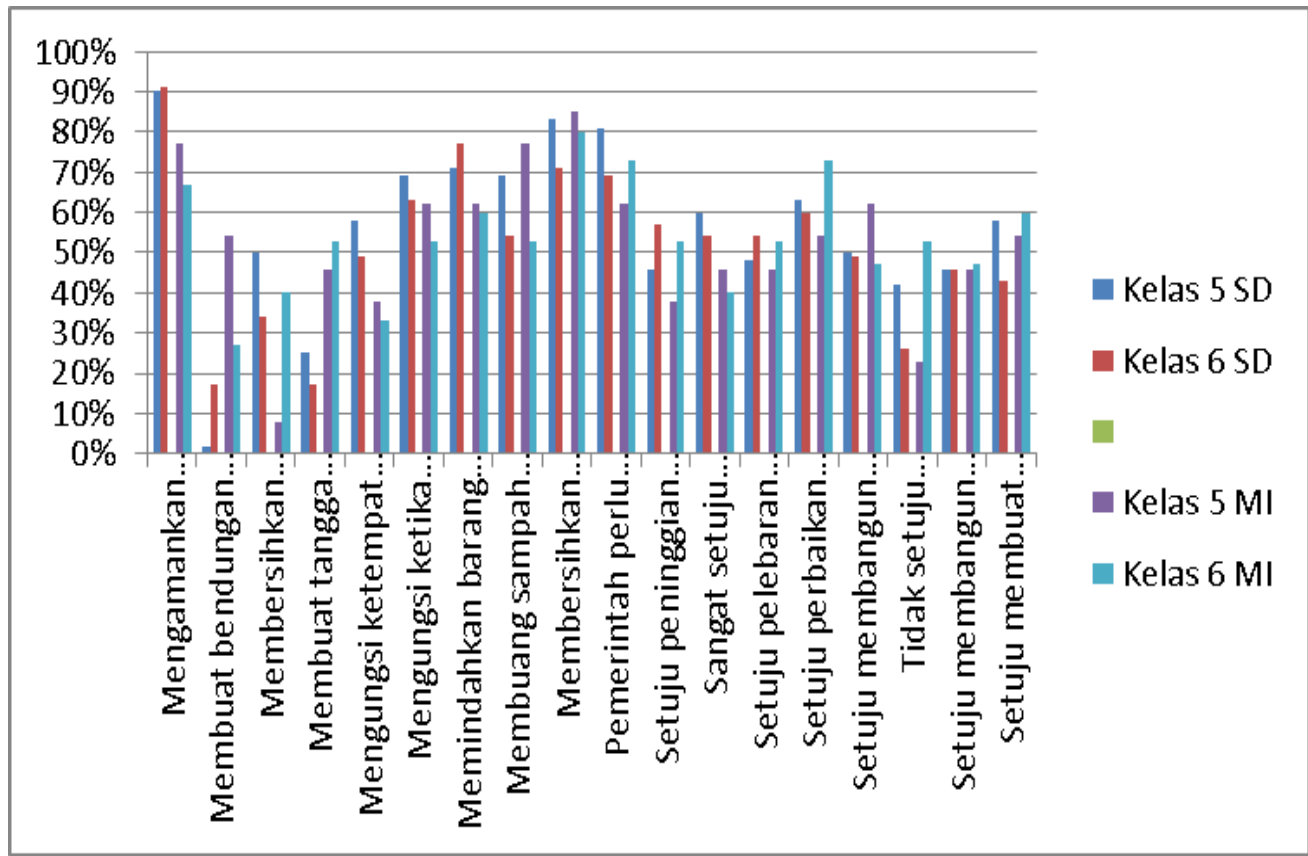

Hasil penelitian menunjukan bahwa $80 \%$ sampai $90 \%$ siswa kelas 5 dan kelas 6 berpendapat bahwa yang harus mereka lakukan jsebagai strategi adaptasi banjir adalah menyelamatkan barang-barang berharga ke tempat yang lebih tinggi dan membersihkan sekolah pasca banjir. Kemudian sekitar $50 \%$ sampai $80 \%$ siswa berpendapat yang harus dilakukan sebagai strategi adaptasi adalah memindahkan barang penting sekolah dan memperbaiki saluran drainase. Karena di SD Muhammadiyah PK Bayat yang mengalami sedikit masalah ada pada saluran drainase.

Sekitar $30 \%$ sampai $50 \%$ siswa menjawab membersihkan saluran air sebagai strategi adaptasi banjir karena siswa dapat melihat bahwa sungai banyak menjadi tempat pembuangan sampah dan tetap besekolah di SD Muhammadiyah PK Bayat walaupun sering banjir karena semenjak sekolah terendam banjir parah, komite sekolah melakukan renovasi jika terjadi hujan lebat, air tidak masuk ke sekolah. Jika terjadi banjir, rumah-rumah siswa yang parah terendam banjir dan siswa tidak masuk sekolah. Selanjutnya, sekitar $0 \%$ sampai $20 \%$ siwa menjawab membuat bendungan kecil di depan pintu rumah. Karena yang menjadi responden kelas 5 dan kelas 6 , jadi belum terlalu memahami apa yang harus dilakukan sebelum, saat dan sudah terjadi bencana banjir.

Hasil penelitian menunjukan bahwa bentuk-bentuk adaptasinya seperti mengamankan barang berharga ke 
tempat yang lebih tinggi, membuat bendungan kecil di pintu rumah, membersihkan saluran air, membuat tangga darurat ke plavon, mengungsi ketika banjir datang, memindahkan barang penting sekolah, membuang sampah di TPS, tetap bersekolah walaupun sekolah rawan banjir, membersihkan sekolah pasca banjir, perlunya perbaikan drainase, peninggian tanggul sungai, penghijauan di sekitar sungai, pelebaran dan pengerukan sungai, perbaikan drainase, membuat sekolah pompa air, penertiban daerah bantaran sungai, membuat peta rawan banjir, tidak setuju membangun sekolah panggung, setuju membangun sekolah panggung, setuju embuat sodetan sungai.

Dilihat dari gambar 4, presentase tertinggi $77 \%$ (siswa kelas 5) untuk pilihan mengamankan barang berharga ke tempat yang lebih tinggi, 54\% (siswa kelas 5) untuk pilihan membuat bendungan kecil di pintu rumah, $40 \%$ (siswa kelas 6) untuk pilihan membersihkan saluran air, 53\% (siswa kelas 6) untuk pilihan membuat tangga darurat pada plavon, 38\% (siswa kelas 5) untuk pilihan mengungsi ke tempat aman, 62\% (siswa kelas 5) untuk pilihan mengungsi ketika banjir, 62\% (siswa kelas 5) untuk pilihan memindahkan barang penting sekolah, $77 \%$ (siswa kelas 5) untuk pilihan membuang sampah di TPS, 85\% (siswa kelas 5) untuk pilihan membersihkan sekolah pasca banjir, $62 \%$ (siswa kelas 5) untuk pilihan tetap bersekolah disana walaupun sering banjir, 13\% (siswa kelas 6) untuk pilihan mungkin tetap bersekolah disana walaupun sering banjir, 73\% (siswa kelas 6) untuk pilihan pemerintah perlu melakukan perbaikan saluran air, 53\% (siswa kelas 6) untuk pilihan setuju peninggian tanggul sungai, 47\% (siswa kelas 5) untuk pilihan sangat setuju penghijauan di sekitar sungai, 53\% (siswa kelas 6) untuk pilihan setuju pelebaran dan pengerukan sungai, $73 \%$ (siswa kelas 6) untuk pilihan perbaikan system drainase, 62\% (siswa kelas 5) untuk pilihan setuju membangun sekolah pompa air, 62\% (siswa kelas 5) untuk pilihan setuju penyusunan peraturan dan penertiban daerah bantaran sungai, $68 \%$ (siswa kelas 6) untuk pilihan setuju membuat peta rawan banjir, 53\% (siswa kelas 6) untuk pilihan tidak setuju membangun sekolah panggung, 47\% (kelas 6) untuk pilihan setuju membangun sekolah panggung, dan 60\% (siswa kelas 6) untuk pilihan setuju membuat sodetan sungai.

Strategi adaptasi siswa dalam menghadi banjir di Madrasah Ibtidaiyah Muhammadiyah Talang, Bayat termasuk dalam tingkat sedang karena rata-rata siswa telah mengerti hal apa saja yang harus dilakukan sebelum dan saat banjir. Akan tetapi perlu adanya peningkatan pengetahuan strategi adaptasi yang baik oleh siswa ketika berhadapan dengan 
banjir karena tidak sedikit siswa yang belum mengerti dan paham hal apa saja yang harus dilakukan sebelum dan saat banjir tersebut melanda. Dibuktikan dengan gambar 4 pada pilihan membersihkan saluran air lebih rendah presentasenya dibandingkan dengan membuat tangga darurat pada plavon, yang berarti banyak siswa yang masih kurang memperhatikan lingkungan sekitar untuk mencegah terjadinya banjir.

\section{KESIMPULAN}

Menurut data historis yang didapat dari kuesioner yang disebar ke responden, kerawanan banjir di SDM PK dan MIM Talang Bayat bisa dikatakan cukup tinggi karena lokasi sekolah yang berdekatan dengan Sungai Dengkeng sehingga memiliki kemungkinan besar terkena banjir saat air sungai meluap karena curah hujan yang tinggi. Akan tetapi kondisi SDM PK Bayat untuk sekarang sudah cukup membaik, karena sudah Adanya renovasi pada bangunan sekolah yang dibuat lebih tinggi dari akses jalan sekitar. Namun Kondisi MIM Talang Bayat masih dalam keadaan kurang baik, karena bangunan sekolahnya yang kurang kokoh dan latar sekolah lebih rendah dari akses jalan sehingga ketika ada banjir dengan ketinggian kurang lebih $70 \mathrm{~cm}$ dan lama banjir lebih dari 8 jam di wilayah tersebut maka air mudah masuk ke dalam sekolah.
Siswa kelas 5 dan kelas 6 SDM PK Bayat sudah sedikit mengetahui apa yang harus dilakukan sebelum dan saat terjadi banjr. Penanaman rasa cinta kebersihan merupakan salah satu strategi yang paling penting, karena jika siswa terbiasa membuang sampah sembarangan dapat menyumbat saluran air dan menyebabkan banjir. Siswa juga mengetahui apa yang harus dilakukan setelah terjadi banjir, seperti mungungsi ke tempat aman, membersihkan lingkungan dari sisa-sisa banjir. Strategi adaptasi siswa dalam menghadapi banjir di MIM Talang, Bayat termasuk dalam tingkat sedang karena rata-rata siswa telah mengerti hal apa saja yang harus dilakukan sebelum dan saat banjir. Akan tetapi perlu adanya peningkatan pengetahuan strategi adaptasi yang baik oleh siswa ketika berhadapan dengan banjir.

\section{DAFTAR PUSTAKA}

Habiba, Nurjihan. Dkk. 2017. Adaptasi Sosial Masyarakat Kawasan Banjir di Desa Bojongloa Kecamatan Rangaekek. Jurnal Pemikiran dan Penelitian Sosiologi, 2 (1), 47-56.

Nasution, Isman Pratama. Dkk. 2011. Kearifan Lokal Tentang Mitigasi Bencana Pada Masyarakat Baduy. Jurnal Makara, Sosial Humaniora, 15 (1), 67-76.

Rosyidie, Arief. 2013. Banjir : Fakta dan Dampaknya, Serta Pengaruh dari Perubahan Guna Lahan. Jurnal 
Perencanaan Wilayah dan Kota, 24

(3), 241-249.

Budi Santoso, Eko. 2013. Manajemen Risiko Bencana Banjir Kali Lamong Pada Kawasan PeriUrban Surabaya-Gresik Melalui Pendekatan Kelembagaan. Jurnal Penataan Ruang, 8 (2), 48-56.

Saud, Ismail. 2007. Kajian Penanggulangan Banjir di Wilayah Pematusan Surabaya Barat. Jurnal Aplikasi: Media Informasi dan Komunikasi Aplikasi Teknik Sipil Terkini, 3 (1), 1-10.

Ritohardoyo, Su. Dkk. 2017. Strategi Adaptasi Masyarakat Pesisir Dalam Penanganan Bencana Banjir Rob dan Implikasinya Terhadap Ketahanan Wilayah (Studi di Desa Bedono Kecamatan Sayung Kabupaten Demak Jawa Tengah). Jurnal Ketahanan Nasiona, 23 (2), 125-144.

Pamungkas, Adjie., \& Rachmat, Adhe Reza. 2014. Faktor-Faktor Kerentanan yang Berpengaruh Terhadap Bencana Banjir di Kecamatan Manggala Kota Makassar. Jurnal Teknik Pomits, 3 (2), 1-5.

Iswardoyo, Jati. 2013. Adaptasi Masyarakat Terhadap Bencana Banjir Lahar Studi Kasus : Kemiringan, Srumbung, Magelang, Jawa Tengah. Jurnal Sosek Pekerjaan Umu, 5 (2), 76139.

Afandi, Akhmad. 2012. Evakuasi Bencana Banjir di Gedung Graha Sainta Fakultas MIPA Universitas
Brawijaya dengan Metode Campus Watching. Jurnal Erudio, 1 (1), 14-17.

Nasyiruddin. Dkk. 2015. Strategi Pemerintah Daerah dalam Penanggulangan Bencana Banjir di Kabupaten Bantaeng. Jurnal Otoritas, V (2), 157-172.

Utama, Erdi Guna., \& Suarmika, Putu Eka. 2017. Pendidikan Mitigasi Bencana di Sekolah Dasar. Jurnal Pendidikan Dasar Indonesia, 2 (2), 18-24.

Badan Pusat Statistika Kabupaten Klaten, 2018. Kecamatan Bayat dalam Angka 2018. Kabupaten Klaten : Badan Pusat Statistik. 